\title{
RESEARCH PAPER \\ Effect of pre- and postpartum body development on the rebreeding of first-calf heifers
}

\author{
Guilherme Joner', Dari C. Alves Filho², Ivan L. Brondani², Sander M. \\ Adams $^{2}$, Amanda F. Moura², Gilmar S. Cardoso², Mauren B. Silva² and \\ Patrícia M. M. Cattelam²
}

${ }^{1}$ Federal University of Pampa, Campus Dom Pedrito. Street 21 de Abril, No80, 96450000, Brazil.

${ }^{2}$ Federal University of Santa Maria, Departament of Zootecnia. Avenue Roraima, №1000, 97105900, Brazil.

\begin{abstract}
G. Joner, D.C. Alves Filho, I.L. Brondani, S.M. Adams, A.F. Moura, G.S. Cardoso, M.B. Silva, and P.M.M. Cattelam. 2019. Effect of pre- and postpartum body development on the rebreeding of first-calf heifers. Cien. Inv. Agr. 46(3):243-252. The objective of this study was to evaluate the effect of live weight and body condition score, measured at different growth stages, on the rebreeding of first-calf heifers. A total of 120 Nellore and Charolais crossbred heifers born between 2004 and 2008 were assessed. Their average age was $26 \pm 1$ months, they were all from the same herd, and they received the same management from birth. To conduct this study, pre- and postpartum measurements of first-calf heifers were taken. The data were submitted to analysis of variance, and the means were compared using Student's t-test at a significance level of $\alpha=0.05$. A higher live weight of the heifer at 24 months enabled early calving within the first calving season $(\mathrm{r}=-0.30)$. First-calf heifers that rebred had a higher live weight at weaning ( $361 \mathrm{~kg} v s .333 \mathrm{~kg}$ ) than those that did not, although their live weights at calving were similar ( $344 \mathrm{~kg} v$ s. $332 \mathrm{~kg}$ ). The rebreeding of first-calf heifers that gave birth with the same body condition score as in the first calving was dependent on positive live weight gain until the end of the following breeding season, especially during the calving-weaning period.
\end{abstract}

Keywords: Calving-to-conception interval, calving season, crossbreeding, live weight at calving, reproductive efficiency.

\section{Introduction}

Ruminant production is one of the activities that aggravates the greenhouse effect that occurs naturally on our planet. Several alternatives seek to improve the nutritional and reproductive efficiencies of production processes in order to

Received May 31, 2018. Accepted Aug 26, 2019.

Corresponding author: guilhermejoner@unipampa.edu.br reduce the emission of noxious gases. Brazil has the second largest commercial herd of cattle on the planet, with 226 million animals (23\%) (USDA, 2017), and has been trying to improve its reproductive efficiency to increase the amount of meat produced per cow per year.

The main obstacle to the reproductive process is the rebreeding of first-calf heifers. These animals have a high nutritional demand because their 
body growth is linked to the production of milk for calves (Mulliniks et al., 2012). The nutrition of heifers and first-calf females is of fundamental importance to guarantee body growth, calf lactation and satisfactory physiological conditions for the new reproductive cycle. Monitoring the animals is important to determine possible actions to correct the animals' live weight (LW) and body condition score (BCS), increasing their reproductive efficiency.

Dry matter intake capacity is lower at this stage of life than in older animals. This fact calls for attention because the forage base of breeding herds consists of natural fields or tropical crops, such as Brachiaria, with variations in forage availability (Tanure et al., 2011) due to environmental factors (specific periods of drought or extremely low temperatures), which may decrease its nutritional value for animals.

The use of crossbreeding is an alternative to improve reproductive efficiency, making animals more adapted to the different environments of the country. Nellore cattle are widely used in crossbreeding systems with Bos taurus breeds since their rustic characteristics allow for the best use of pasture intake. In crossbreeding, $B$. taurus animals contribute to precocious puberty and growth performance (Restle et al., 2007).

Thus, the aim of this study was to evaluate the effect of LW and BCS, measured pre- and postpartum, on the rebreeding of first-calf heifers from different contemporary and genetic groups.

\section{Materials and Methods}

The procedures were in accordance with the Institutional Committee for the Care of Animals in Experimentation (CEUA, Federal University of Santa Maria, UFSM). The study was carried out in the Laboratório de Bovinocultura de Corte ( $L B C$ ) (Beef Cattle Laboratory) of the Departamento de Zootecnia (Department of Zootechnics) of the Federal University of Santa Maria, city of Santa Maria, located in the Central Depression of the State of Rio Grande do Sul (Brazil), at an average elevation of $95 \mathrm{~m}, 29^{\circ} 43^{\prime}$ south latitude and $53^{\circ} 42^{\prime}$ west longitude.

The climate of the region is "Cfa" (humid subtropical), according to the Köppen classification. The average annual rainfall is $1651 \mathrm{~mm}$, the average annual temperature is $19^{\circ} \mathrm{C}$, and the minimum and maximum average temperatures are 10 and $30{ }^{\circ} \mathrm{C}$ in the months of August and January, respectively. The average sunshine duration is 2212 hours per year, and the relative humidity is 73\% (Alvares et al., 2013).

In this study, 120 heifers belonging to the 4 th $(11 / 16 \mathrm{Ch} 5 / 16 \mathrm{Ne} ; 11 / 16 \mathrm{Ne} 5 / 16 \mathrm{Ch})$ and 5 th $(21 / 32 \mathrm{Ch}$ $11 / 32 \mathrm{Ne} ; 21 / 32 \mathrm{Ne} 11 / 32 \mathrm{Ch}$ ) generations of Charolais (Ch) and Nellore ( $\mathrm{Ne}$ ) continuous crossbreeding were evaluated. They were born between 2004 and 2008 and divided into two groups during the reproductive stage, one consisting of primiparous animals that had their second calving $(n=44)$ and the other of first-calf heifers that did not breed in the second breeding season ( $\mathrm{n}=76)$, according to Charolais $(n=65)$ or Nellore $(n=55)$ genetic predominance.

All the heifers evaluated were weaned early at \pm 75 days and then managed in one of the cultivated pastures in the first summer (elephant grass, millet, Alexander grass or Tifton 85), followed by black oat plus ryegrass (winter pasture), both with energy supplementation ( $1 \%$ of LW). In the second summer and throughout their reproductive lives, the heifers received the same nutritional management as the herd, i.e., native grass forages (average animal load of $350 \mathrm{~kg} \mathrm{ha}^{-1}$ ) with mineral supplementation based on sodium chloride and dicalcium phosphate. The characteristics of existing native fields included the presence of shrubs and the widespread existence of caespitose plants in the transition area of the Pampa and Atlantic Forest biomes. The herd management area has been invaded by Annoni grass (Eragrostis plana 
Nees), $a$ plant that is undesirable because of its low nutritional value and very aggressive effect on other plants due to its allelopathic capacity, which reduces the biodiversity of the system. More information on the characteristics of the productive system adopted by the farm can be found in Silveira et al. (2014).

Heifers entered the reproductive process at a mean age of $26 \pm 1$ months. Their breeding season lasted 90 days: the first 45 days (12/01 to 01/13) were used for artificial insemination, and the remaining 45 days (01/14 to $02 / 28)$ were used for natural breeding with bulls (1:30-40). Pregnancy diagnosis was performed by rectal palpation 60 days after the end of the breeding season. The approximate calving period lasted from September 15 ("day 1" of the calving season) to December 15 , and weaning was performed at a mean age of 75 days postpartum.

To conduct this study, the following measurements of first-calf heifers from the database were used: genetic group; year of birth; cow age; calving order; calving date; LW (18 months, 24 months, end of breeding, calving and weaning); and BCS (end of breeding, pregnancy diagnosis and calving). LW and BCS at calving were obtained within the first 24 hours after calving. BCS was measured according to a 5-point scale, where $1=$ very thin, $2=$ thin, $3=$ average, $4=$ fat and $5=$ very fat (Lowman et al., 1973). For information on the adult LW of cows, data from animals slaughtered $(n>150)$ in the same period and with the same genotypes as in this study were used. The mean genotypes ranged from 495 to $510 \mathrm{~kg}$; thus, a mean LW of $500 \mathrm{~kg}$ was considered. According to the variation in means, animals with Charolais genetic predominance showed a mean adult LW $2 \%$ higher than that of animals with Nellore genetic predominance. Mathematical functions that best fit the point distribution were used to prepare a chart of calving distribution within the calving season. Distributions of interval frequencies of calvings within the calving seasons were also prepared using Sturges' formula after calculating the range of the class interval.

Statistical Analysis System (SAS, version 9.2, 2009) was used for statistical analysis. After no significant interactions between the effects (animal group, genetic predominance, and contemporary group) were found, the mathematical model adopted for all the variables was the following:

$\mathrm{Yijkl}=\mu+\mathrm{GAi}+\mathrm{GGk}+\varepsilon \mathrm{ijk} \mathrm{l}$, where

Yijkl=dependent variables; $\mu=$ mean of all observations; $\mathrm{GAi}=$ effect of the $\mathrm{i}$-th animal group (rebred or not rebred); GGk= effect of the k-th genetic predominance (Charolais or Nellore); and $\varepsilon \mathrm{ijkl}=$ residual random error.

The data were submitted to an analysis of variance using the PROC GLM procedure. The Kolmogorov-Smirnov test was used to assess the normality of residuals at a 5\% significance level. For the variables that did not follow a normal distribution, constants were used to reach residual normality, such as log constants for LW at 24 months and squared values for cow LW at the second calving. The means were compared using Student's t-test with an $\alpha=0.05$ probability. The correlation between the variables studied was also calculated using the PROC CORR command.

\section{Results and Discussion}

Measurements performed during the development of the primiparous animals did not show a significant interaction $(P<0.05)$ between class variables (rebreeding, genetic predominance and contemporary group). To evaluate the nutritional quality provided to the animals, it is necessary to monitor LW and BCS. BCS is the measurement used to evaluate body fat deposition, which is measured by visually scoring the amount of subcutaneous fat present in the animal. It is a subjective measure; however, according to Silveira et al., (2014), it is a simple and low-cost option 
for assessing the nutritional status of animals, in turn assisting in strategic decision making to improve the reproductive and nutritional efficiencies of herds.

The feeding dynamics employed in the breeding system were the same throughout the study, and the differences found in the measurements were dependent on genetics and the adaptation of each animal to the adopted reproductive program. Moraes et al. (2013), when studying postpartum BCS in different pastoral environments, found that the use of adequate food management (modifying stocking, adjusting breeding seasons and implementing sanitary systems) for cows in postcalving increased the reproductive rate of females. Moreover, better animal nutritional levels trigger better biological efficiency results (Restle et al., 2007).
Animals with Ne genetic predominance showed lower LW values than animals with a Ch genetic prevalence at similar ages (Table 1). According to Pacheco et al. (2013), a faster live weight gain (LWG) can be attributed to animals with predominantly $\mathrm{Ch}$ genetics, while there is greater precocity in the deposition of body fat in animals with Ne genetic predominance. The authors found in their study that animals with $\mathrm{Ne}$ genetic predominance presented a shorter carcass length (122 vs. $117 \mathrm{~cm}$ ) and smaller loin eye area/100 $\mathrm{kg}$ of cold carcass $\left(34\right.$ vs. $29 \mathrm{~cm}^{2}$ ) than animals with $\mathrm{Ch}$ genetic predominance. Moreover, since the first-calf heifers evaluated belonged to the 4th and 5th crossbreeding generations, the difference found cannot be attributed to heterosis since the animals were distributed among the different groups (treatment, year of birth and genetic predominance).

Table 1. Means of live weight (LW) and body condition score (BCS) during the reproductive period of first-calf cows according to positive or negative calving repetition and genetic predominance.

\begin{tabular}{|c|c|c|c|c|c|c|c|}
\hline \multirow[b]{2}{*}{ Variables } & \multicolumn{2}{|c|}{ Group of Animals } & \multicolumn{2}{|c|}{ Genetic Group } & \multirow[b]{2}{*}{ SEM } & \multicolumn{2}{|c|}{ Probability } \\
\hline & Rebred & $\begin{array}{c}\text { Not } \\
\text { Rebred }\end{array}$ & $\begin{array}{c}\text { Predo } \\
\text { Ch }\end{array}$ & $\begin{array}{c}\text { Predo } \\
\mathrm{Ne}\end{array}$ & & GA & GG \\
\hline LW at 18 months, $\mathrm{kg}$ & 287 & 269 & 287 & 270 & 38 & 0.0618 & 0.0180 \\
\hline LW at 24 months, $\mathrm{kg}$ & 328 & 302 & 331 & 299 & 33 & 0.0049 & $<0.0001$ \\
\hline LW at Final $1^{\text {st }}$ mating, $\mathrm{kg}$ & 405 & 378 & 401 & 381 & 39 & 0.0092 & 0.0159 \\
\hline BCS at Final $1^{\text {st }}$ mating, points & 2.89 & 2.86 & 2.83 & 2.92 & 0.13 & 0.7337 & 0.0275 \\
\hline LW at $1^{\text {st }}$ pregnancy diagnosis, $\mathrm{kg}$ & 394 & 384 & 395 & 383 & 37 & 0.4541 & 0.3648 \\
\hline $\mathrm{BCS}$ at $1^{\text {st }}$ pregnancy diagnosis, points & 2.79 & 2.74 & 2.73 & 2.80 & 0.12 & 0.3048 & 0.0199 \\
\hline LW at $1^{\text {st }}$ calving, $\mathrm{kg}$ & 344 & 332 & 345 & 331 & 36 & 0.1512 & 0.0311 \\
\hline $\mathrm{BCS}$ at $1^{\text {st }}$ calving, points & 2.21 & 2.19 & 2.22 & 2.18 & 0.27 & 0.7208 & 0.4375 \\
\hline $\mathrm{LW}$ at $1^{\text {st }}$ weaning ${ }^{\dagger}, \mathrm{kg}$ & 361 & 333 & 358 & 337 & 41 & 0.0262 & 0.0644 \\
\hline LW at Final $2^{\text {nd }}$ mating, $\mathrm{kg}$ & 380 & 354 & 381 & 353 & 34 & 0.0031 & 0.0008 \\
\hline BCS at Final $2^{\text {nd }}$ mating, points & 2.67 & 2.54 & 2.62 & 2.60 & 0.16 & 0.0027 & 0.6586 \\
\hline $\mathrm{BCS}$ at $2^{\text {nd }}$ pregnancy diagnosis, points & 2.57 & 2.33 & 2.46 & 2.44 & 0.19 & 0.0006 & 0.8102 \\
\hline $\mathrm{LW}$ at $2^{\text {nd }}$ calving, $\mathrm{kg}$ & 388 & - & 400 & 376 & 45 & - & 0.0651 \\
\hline $\mathrm{BCS}$ at $2^{\text {nd }}$ calving, points & 2.37 & - & 2.37 & 2.37 & 0.26 & - & 0.9373 \\
\hline $\mathrm{LW}$ at $2^{\text {nd }}$ weaning ${ }^{\ddagger}, \mathrm{kg}$ & 415 & - & 408 & 421 & 55 & - & 0.6323 \\
\hline
\end{tabular}

'mean live weight at calf weaning was similar between genetic predominances $(81 \mathrm{~kg})$;

mean live weight at calf weaning between genetic predominances (Nellore: $93 \mathrm{~kg}$ and Charolais: $84 \mathrm{~kg}$ );

$\mathrm{LW}=$ live weight; $\mathrm{BCS}=$ body condition score; Predo $\mathrm{Ch}=$ Charolais genetic predominance; Predo Ne=Nellore genetic predominance; $\mathrm{GA}=$ group of animals; $\mathrm{GG}=$ genetic group. 
In the first measurement of the animals' LW at 18 months of age, heifers with $\mathrm{Ch}$ genetic predominance presented higher LWs $(287 \mathrm{~kg} v s$. $270 \mathrm{~kg}$ ). Studies have shown that LW at puberty varies considerably among bovine breeds since they present different LWs in adulthood. LW at puberty ranges from $60-70 \%$ of the adult LW, depending on the contribution of zebu cattle to the cross (genetic complementarity). When zebu cattle make a greater genetic contribution to the cross and/or specific breed, the LW percentage tends to be closer to 70\% (Di Marco, 2006).

The LWs of the heifers at 18 and 24 months showed significant positive correlations $(P>0.05)$ with the other LW measurements at the following ages (Table 2), demonstrating that LW results from body growth over time. A high LW for heifers at 18 months favors pregnancy in the second breeding season, which can be verified by the negative correlation $(-0.31, P=0.0412)$ obtained according to the calving distribution within the second calving season. The LW of the heifers at 24 months showed a negative correlation (-0.30, $P=0.0038)$ with the calving distribution within the first calving season. The calving distributions within the two calving seasons (CSs) were correlated $(0.53 ; P=0.0002)$, demonstrating that first-calf heifers tended to give birth later in the following CS over the years until it was no longer successful, considering the reproductive protocol imposed by the system. In this way, it is important that the heifer breed as early as possible in the first breeding season.

LW measurements performed at 24 months of age and at the end of the breeding season also showed differences between the genetic predominances and groups evaluated. At the end of the first breeding season, the groups of animals had the same mean BCS, differing only in terms of genetic dominance, resulting in more subcutaneous fat in animals with Ne genetic predominance, even if they had a lower LW than animals with Ch genetic predominance. According to (Restle et al., 2007), higher LWs at the end of the season are favorable for the cows during the winter period, which is characterized by low vegetation growth in native fields, and allow them to enter spring calving with a better BCS.

Table 2. Correlations of body weight (BW) and body condition score (BCS) during the reproductive period of first-calf cows.

\begin{tabular}{|c|c|c|c|c|c|c|c|c|c|c|c|c|c|c|c|c|c|c|}
\hline \multirow{2}{*}{\multicolumn{2}{|c|}{ Variables }} & \multicolumn{6}{|c|}{ BW1 } & \multicolumn{3}{|c|}{ BCS1 } & \multirow{2}{*}{$\mathrm{CS} 1$} & \multicolumn{3}{|c|}{ BW2 } & \multicolumn{3}{|c|}{ BCS2 } & \multirow{2}{*}{$\mathrm{CS} 2$} \\
\hline & & 18 & 24 & FM & PG & $\mathrm{Cal}$ & $\mathrm{W}$ & FM & PG & $\mathrm{Cal}$ & & FM & $\mathrm{Cal}$ & W & FM & PG & $\mathrm{Cal}$ & \\
\hline \multirow[t]{6}{*}{ BW1 } & 18 & 1 & & & & & & & & & & & & & & & & \\
\hline & 24 & $0.55^{*}$ & 1 & & & & & & & & & & & & & & & \\
\hline & FM & $0.63^{*}$ & $0.88^{*}$ & 1 & & & & & & & & & & & & & & \\
\hline & PG & $0.77^{*}$ & $0.63^{*}$ & $0.92 *$ & 1 & & & & & & & & & & & & & \\
\hline & $\mathrm{Cal}$ & $0.44^{*}$ & $0.56^{*}$ & $0.68 *$ & $0.64^{*}$ & 1 & & & & & & & & & & & & \\
\hline & $\mathrm{W}$ & $0.69^{*}$ & $0.72^{*}$ & $0.79 *$ & $0.75^{*}$ & $0.90^{*}$ & 1 & & & & & & & & & & & \\
\hline \multirow[t]{3}{*}{ BCS1 } & FM & 0.07 & 0.04 & 0.10 & 0.00 & -0.13 & -0.05 & 1 & & & & & & & & & & \\
\hline & PG & -0.20 & $-0.36^{*}$ & -0.24 & 0.06 & -0.14 & 0.12 & $0.46^{*}$ & 1 & & & & & & & & & \\
\hline & $\mathrm{Cal}$ & 0.11 & 0.09 & 0.07 & -0.07 & $0.50 *$ & $0.34 * *$ & -0.09 & -0.14 & 1 & & & & & & & & \\
\hline $\mathrm{CS} 1$ & & -0.14 & $-0.30 *$ & $-0.37 *$ & -0.27 & 0.10 & -0.12 & -0.09 & 0.17 & $0.45^{*}$ & 1 & & & & & & & \\
\hline \multirow[t]{3}{*}{ BW2 } & FM & $0.48^{*}$ & $0.70^{*}$ & $0.80^{*}$ & $0.66^{*}$ & $0.72 *$ & $0.81^{*}$ & 0.21 & -0.22 & $0.22 * *$ & $-0.29^{*}$ & 1 & & & & & & \\
\hline & $\mathrm{Cal}$ & $0.55^{*}$ & $0.70 *$ & $0.78 *$ & $0.83^{*}$ & $0.66^{*}$ & $0.75^{*}$ & 0.30 & 0.11 & 0.07 & -0.15 & $0.82 *$ & 1 & & & & & \\
\hline & $\mathrm{W}$ & $0.60^{*}$ & $0.58 * *$ & $0.78^{*}$ & $0.81^{*}$ & $0.70^{*}$ & $0.90^{*}$ & 0.27 & 0.29 & 0.13 & -0.16 & $0.83^{*}$ & $0.90^{*}$ & 1 & & & & \\
\hline \multirow[t]{3}{*}{ BCS2 } & FM & $0.36^{*}$ & -0.10 & -0.14 & 0.25 & 0.02 & 0.29 & . & -0.04 & $0.42 * *$ & 0.06 & 0.16 & 0.07 & 0.45 & 1 & & & \\
\hline & PG & $0.47^{*}$ & 0.09 & 0.20 & 0.34 & 0.18 & 0.28 & . & 0.12 & -0.18 & $-0.44^{*}$ & $0.38^{* *}$ & 0.06 & 0.41 & $0.60^{*}$ & 1 & & \\
\hline & $\mathrm{Cal}$ & 0.10 & $0.47^{*}$ & $0.35^{* *}$ & $0.53^{* *}$ & 0.18 & 0.21 & 0.41 & -0.01 & -0.01 & -0.15 & $0.37^{* *}$ & $0.63^{*}$ & $0.54^{* *}$ & -0.29 & -0.32 & 1 & \\
\hline $\mathrm{CS} 2$ & & $-0.31 * *$ & -0.07 & -0.19 & -0.12 & 0.04 & -0.19 & 0.03 & 0.12 & 0.03 & $0.53^{*}$ & -0.15 & 0.13 & -0.19 & $-0.45^{*}$ & $-0.51^{*}$ & 0.20 & 1 \\
\hline
\end{tabular}

$* \mathrm{P}<0.01$

** $\mathrm{P}<0.05$

$1=$ first year; $2=$ second year; $\mathrm{CS}=$ calving season; $18=18$ months; $24=24$ months; $\mathrm{FM}=$ final mating; $\mathrm{PG}=$ diagnosis; $\mathrm{Cal}=$ calving; $\mathrm{W}=$ weaning. 
The LW at calving (Table 1) differed depending on genetic predominance, with $345 \mathrm{~kg}$ (69\% of adult LW) for first-calf heifers with $\mathrm{Ch}$ predominance compared to $331 \mathrm{~kg}$ ( $66 \%$ of adult LW) for those with Ne genetic predominance. Vaz and Lobato (2010), when evaluating Braford first-calf heifers, found an LW at calving of $312 \mathrm{~kg}$, lower than that in the present study, whereas the BCS at the first calving was 2.32 points, close to the values found in this study.

According to Ferreira (2010), cows that maintained an average BCS during gestation and that maintained their LW after calving took less time to show the first postpartum estrus. The maintenance of BCS and LW after calving allows leptin production to remain constant, enabling the reproductive cycle to be triggered (Ferreira, 2010). In Brazil, nutritional deficiency of cows is the main cause of anestrous in cattle, almost all of which is classified as true and deep. In this study, it was found that the BCS of heifers at the first calving correlated positively $(0.45)$ with the occurrence of calving within the first CS (Table 2). However, according to Ferreira (2010), a high BCS at calving also entails significant complications during calf birth, where scores should not exceed 3.5 points on a 5-point scale.

An average BCS loss of 1.35 points was observed by Tanure et al. (2011) for all animals from pregnancy diagnosis to calving when evaluating different types of nutritional management in native fields. In a review article, Crowe (2008) concluded that the key to better ovulation performance in cattle was the maintenance of the BCS, such that they did not calve with a score below 2.75 points on a 5-point scale and did not lose 0.5 points in the postpartum period. In this study (Table 1), first-calf heifers had a BCS of approximately 2.75 points at the first pregnancy diagnosis, but they lost more than $0.5 \mathrm{BCS}$ points before calving. The loss of BCS points was more pronounced in first-calf heifers with $\mathrm{Ne}$ genetic predominance, who lost 0.62 BCS points. Even with a loss greater than 0.50 points, there were still first-calf heifers that were able to rebreed in the following year, showing that there are other variables concomitantly involved in improving the reproductive performance of first-calf heifers.

The animals were able to recover their LW and BCS at the first calving, but the difference between the animals that could rebreed and those that could not persisted. According to Moraes et al. (2013), pregnancy rates remain below the desired rate when lactating cows present a decrease in the BCS to less than 3 points or an increase of 1 point from 2 points. The authors reached this conclusion when they evaluated the interval from the beginning of the reproductive period to pregnancy diagnosis, emphasizing the dependence on the food management used in this period. This period comprises the fall and winter seasons, during which, as previously described, there is a decrease in vegetation growth in the native fields present in the Pampa biome. It is also possible to relate the results obtained by Moraes et al. (2013) to the production of leptin in the body of the cows. If the BCS drops below 3 and there is a consequent decrease in body fat content, a lower level of leptin will be formed. However, if the BCS increases to greater than 2 points, there will be leptin production and circulation in the body, but with the BCS at this level, the cow's LW is not sufficient to promote a new pregnancy.

Based on the data presented in Table 1, there was a gain of LW in the weaning period at the end of the breeding season, but at the time of the pregnancy diagnosis, the BCS decreased. The decrease in the score was different among treatments, as females that calved again lost 0.10 points while those that did not calve lost 0.21 points between the end of the breeding season and pregnancy diagnosis. However, this drop was independent of genetic predominance since both types of females lost $0.16 \mathrm{BCS}$ points. These results show that the lower animal performance during this period, due to reduced nutritional quality and/or later lactation, prevented rebreeding in order to give priority to the metabolism of the animal. 
The rebreeding rate was low (37\%), where the rate of Ch-predominant cows was $27 \%$ and the rate of Ne-predominant cows was $48 \%$. Although there was a smaller LW gain between calving and weaning ( $6 \mathrm{~kg} v s .13 \mathrm{~kg}$ ), Ne-predominant animals presented the best response in terms of rebreeding in the evaluated population (48\%). BCS was not a determinant of the rebreeding of Ne-predominant animals, as they did not present a significant difference in $\mathrm{BCS}$ at the end of the breeding season in relation to the $\mathrm{Ch}$-predominant animals $(2.60 \mathrm{vs}$. 2.62 points). As shown in Table 1, heifers presented no difference in BCS between animal groups (2.21 vs. 2.19 points) or genetic predominances ( $2.22 v s$. 2.18 points). As previously mentioned, the BCS measured at the end of the second breeding season did not show a significant difference between genetic predominances but did differ between animal groups that were able to rebreed or not (2.67 vs. 2.54 points). Under the conditions of this study, LW gain between calving and weaning had a greater influence on rebreeding than did LW gain between weaning and the end of the breeding season. BCS remained more important than LW at the end of the second breeding season for predicting whether cows would rebreed.

LW gain after calving is of great importance since there is a greater production of leptin in first-calf heifers, thus leveraging the onset of gonadotropin secretion (Barb et al., 2008). Leptin regulates the resumption of reproductive function (Ferreira, 2010) because it communicates the nutritional status of the animal to the central nervous system, through the amounts of triglycerides present in the adipose tissue. In a study conducted in the same location as this one, Silveira et al. (2014) found that the average daily LW gain of breeding cows was $200 \mathrm{~g}$ (end of breeding season - calving). In this study, the cows presented an average daily LW gain of $183 \mathrm{~g}$ in the group that did not rebreed and $300 \mathrm{~g}$ in the group that rebred.

The calving distribution within the first CS (Figure 1) presented a negative correlation (-0.29) with LW at the end of the following breeding season and the BCS at pregnancy diagnosis (0.44) (Table 2), probably due to the shorter period of recovery from weaning to end-of-breeding weighing for cows with insufficient LW and BCS. Low animal performance between end-of-breeding weighing and calving (Table 1) resulted in a longer second calving season (in terms of days) for cows that calved late in the first CS. The correlation between calving seasons was 0.53 . Thus, cows presenting a higher LW and BCS close to calving were able to gain less LW in order to recover physiologically for a new conception.

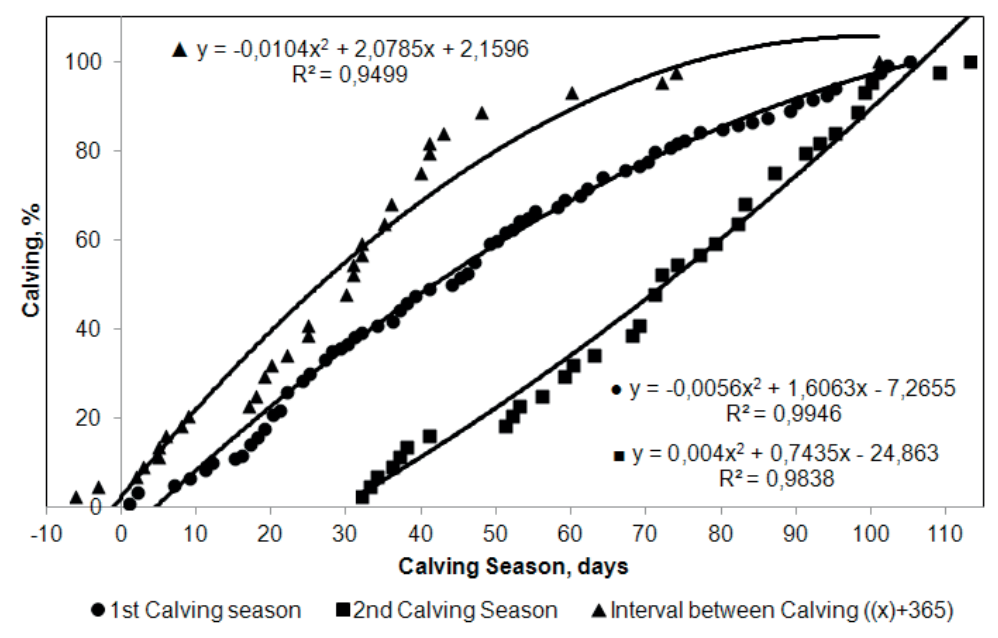

Figure 1. Distribution of calving within the calving season and interval between calvings. 
Figure 1 shows calving distributions within the first and second CSs and the interval between calving. In the first CS, heifers calved at 46 days on average, close to the middle of the CS. Female bovines have an average gestation period of 280 days, but different breeds have different gestation periods. Ne animals, for example, have a longer gestation period than Ch animals (Ferreira, 2010). This difference is only a few days, but in regard to the postpartum recovery of animals, it becomes very important. Normally, the breeding season has specific time standards for the herd of cows, such that animals with shorter gestation periods have more time to recover their LW and BCS before a new conception.

The calving distribution within the second CS presented an average of 72 days among first-calf heifers that rebred (37\%), advancing 26 days compared to the average of the first CS in which they calved. The attention paid to this category is greater because they are still in the body growth stage but are already in the production system, participating in the reproductive process. A longer interval between calvings in first-calf heifers for three consecutive breeding seasons is related to the fact that they are calving for the first time and have high nutritional requirements (maintenance + growth + lactation) compared to adult cows (maintenance + lactation) (Vaz and Lobato, 2010).

The anticipation of getting heifers into the breeding season is aimed at decreasing the interval between puberty and first calving, increasing the number of offspring produced per cow, accelerating the genetic progress of the herd, and reducing greenhouse gas emissions per kilogram of calf weaned during its period in the production system (Boer et al., 2011). Concerns about greenhouse gas emissions in recent years have frequently focused on the contribution of agribusinesses to global warming, especially the production of ruminants, thus provoking the search for better zootechnical indexes that result in improved production efficiency and environmental relationships.
As mentioned before, farms adopt specific periods for the breeding season in order to improve agricultural management/control and the standardization of animal categories for handling and commercialization. When cows become pregnant at the beginning of the breeding season, they will calve at the beginning of the CS, thus having more time for uterine involution and recomposition of muscular and adipose tissues, which should be sufficient to ensure a new pregnancy due to the hormone release that will be triggered (Barb et al., 2008).

The average difference between the first and second CSs was 30 days, and $45 \%$ of the cows that rebred had an interval shorter than 28 days. At a 45 -day interval, $86 \%$ of the cows conceived, evidencing the low performance in terms of LW gain of cows in the postpartum period. Considering a breeding season of 90 days and a mean interval of 45 days between subsequent calvings for more than $85 \%$ of the animals, it can be inferred that the animals could be ready to calve again. However, only $56 \%$ of these first-calf heifers were able to adapt physiologically and physically for a new gestation.

According to the correlations obtained, Table 2 shows that the anticipation of calving in the second CS is conditioned by the period when calving occurred in the previous CS (0.53) and by BCS monitoring of first-calf heifers at the end of the breeding season (0.46) and at pregnancy diagnosis $(0.51)$ for the calving in question.

The BCS at the end of the second breeding season had a correlation (0.42) with the BCS at the first calving, thus demonstrating the importance of a good nutritional status of the cow. The BCS at the pregnancy diagnosis of first-calf heifers had positive correlations with the LW and BCS at the end of the breeding season ( 0.38 and 0.60 , respectively) and a negative correlation with the calving interval within the first CS (-0.44).

Measurements taken at the second calving and weaning did not show a significant difference 
between genetic predominances. It was found that the animals were in the process of body development for adulthood since, at this time, the LW at calving ( $78 \%$ of adult weight) was higher than that at the first calving $(69 \%)$ for the same cows.

The LW at the second weaning demonstrated the development of first-calf heifers as they aged $(83 \%$ of adult weight) compared to the first weaning (72\% of adult weight). Cow performance from calving to weaning was different between the first and second calvings. In the first calving, cows with $\mathrm{Ch}$ genetic predominance showed a greater LW gain from calving to weaning, which was not observed in the second calving, in which cows with Ne genetic predominance presented better LW recovery.

The main conclusions are as follows. Heifers with a higher LW by the end of the first breeding season will rebreed more easily in the following year. First-calf heifers that calve with the same BCS are dependent on positive LWG until the end of the next breeding season, especially during the calving-weaning period. First-calf heifers with Nellore genetic predominance have a better reproductive efficiency than Charolais-genetically predominant animals because after the second calving, the former present higher rebreeding indexes, increased LW gains from calving to weaning, and higher calf weaning weights.

\section{Resumen}

G. Joner, D.C. Alves Filho, I.L. Brondani, S.M. Adams, A.F. Moura, G.S. Cardoso, M.B. Silva, y P. M. M. Cattelam. 2019. Efecto del desarrollo corporal pre y post parto en la reproducción de las novillas de la primera cría. Cien. Inv. Agr. 46(3):243-252. El objetivo de este estudio fue evaluar el efecto del peso vivo y la puntuación de condición corporal, medido en diferentes fases de crecimiento, sobre la repetición de la cría en primíparas. Se evaluaron 120 novillas cruzadas Nellore con Charoles nacidas entre los años 2004 y 2008, con edad media de $26 \pm 1$ meses siendo todas oriundas del mismo rebaño y que reciben idéntico manejo desde el nacimiento. Para la realización de este estudio se utilizaron de la base de datos a las mediciones de la primípara en el pre y post-partos. Los datos fueron sometidos al análisis de varianza y las medias comparadas a través del test " $t$ " de Student, a $\alpha=0,05$ de probabilidad. El mayor del peso vivo de la novilla a los 24 meses proporciona que el parto ocurra por adelantado dentro de la primera estación de parición $(\mathrm{r}=-0,30)$. Primíparas que repetían crea presentaron mayor peso vivo al destete (361 kg vs. $333 \mathrm{~kg}$ ) de las que no repitieron crea, aunque hubiera peso vivo al parto semejante entre sí (344 kg vs. $332 \mathrm{~kg}$ ). La repetición de la cría de primíparas que paren con la misma puntuación de condición corporal, en el primer parto, es dependiente de la ganancia de peso vivo positivo hasta el final de la estación de montaje siguiente, principalmente en el período parto-destete.

Palabras clave: Cruzamiento, eficiencia reproductiva, estación de parición, intervalo partoconcepción, peso vivo al parto. 


\section{References}

Alvares, C.A., J.L. Stape, P.C. Sentelhas, J.L.M. Gonçalves, and G. Sparovek. 2013. Köppen’s climate classification map for Brazil. Meteorol. Z. 22:721-728. doi: 10.1127/0941-2948/2013/0507

Barb, C.R., G.J. Hausman, and C.A. Lents. 2008. Energy metabolism and leptin: effects on neuroendocrine regulation of reproduction in the gilt and sow. Reprod. Domest. Anim. 43:324-330. doi: 10.1111/j.1439-0531.2008.01173.x

Boer, I.J.M., C. Cederberg, S. Eady, S. Gollnow, T. Kristensen, M. Macleod, M. Meul, T. Nemecek, L.T. Phong, G. Thoma, H.M.G. Van Der Werf, A.G. Williams, and M.A. ZonderlandThomassen. 2011. Greenhouse gas mitigation in animal production: towards an integrated life cycle sustainability assessment. Curr. Opin. Environ. Sustain. 3:423-431. doi: 10.1016/j.cosust.2011.08.007

Crowe, M.A. 2008. Resumption of Ovarian Cyclicity in Post-Partum Beef and Dairy Cows. Reprod. Domest. Anim. 43:20-28. doi: 10.1111/j.14390531.2008.01210.x

Di Marco, O.N., J.O.J. Barcellos, and E.C. Costa. 2006. Crescimento de bovinos de corte. Porto Alegre: Universidade Federal do Rio Grande do Sul, pp. 248 .

Ferreira, A. de M. 2010. Reprodução da fêmea bovina - fisiologia aplicada e problemas mais comuns (causas e tratamentos). Juiz de Fora: Minas Gerais - Brasil, pp.422.

Lowman, B.G., N. Scott, and S. Somerville. 1973. Condition scoring beef cattle. Bulletin $n^{\circ} 6$, Edinburgh: East of Scotland College of Agriculture, pp. 8 .

Moraes, J.C.F., C.J. Hoff de Souza, C.C. Brauner, M.A. Pimentel, M.V. Benavides, and J.B.S. Ferraz. 2013. Utilização do escore de condição corporal pós-parto na identificação de vacas de corte mais férteis criadas em sistemas extensivos. Arch. Latinoam. Prod. Anim. 21:149-155.
Mulliniks, J.T., S.H. Cox, M.E. Kemp, R.L. Endecott, R.C. Waterman, D.M. Vanleeuwen, and M.K. Petersen. 2012. Relationship between body condition score at calving and reproductive performance in young postpartum cows grazing native range. J. Anim. Sci. 90:2811-2817. doi: 10.2527/jas.2011-4189

Pacheco, R.F., J. Cattelam, P.A.M.M. Donicht, L.R. Segabinazzi, A.M. Callegaro, E.D. Chieza, G. Joner, J. Restle, D.C. Alves Filho, and I.L. Brondani. 2013. Carcass characteristics and primary cuts of young cattle, feedlot finished. Magistra, 25:138-147.

Restle, J., P.S. Pacheco, A.K. Freitas, I.L. Brondani, J.T. Padua, J.J.R. Fernandes, and D.C. Alves Filho. 2007. Influência das taxas de ganho de peso pré-desmame das vacas e do tipo de pastagem no período pós-parto sobre a eficiência biológica de vacas e de bezerros de corte. R. Bras. Zootec. 36:874-880.

Silveira, M.F., J. Restle, D.C. Alves Filho, R.L. Missio, P.A.M.M. Donicht, L.R. Segabinazzi, A.M. Callegaro, and G. Joner. 2014. Suplementação com gordura protegida para vacas de corte desmamadas precocemente mantidas em pastagem natural. Arq. Bras. Med. Vet. Zootec. 66:809-817.

Tanure, S., B.A.A. Pötter, and J.F.P. Lobato. 2011. Natural and improved natural pastures on the reproductive performance of first-calf beef cows. R. Bras. Zootec. 40:690-699.

USDA - United States Department of Agriculture. 2017. Livestock and Poultry: World Markets and Trade. Foreign Agricultural Service. Retreived from: https://apps.fas.usda.gov/psdonline/ circulars/livestock_poultry.pdf.

Vaz, R.Z., and J.F.P. Lobato. 2010. Effects of the weaning age of calves on somatic development and on reproductive performance of beef cows. R. Bras. Zootec. 39:1058-1067. 